\title{
Proposed Remedies to Prevent Road Traffic Accidents (RTAs) on Highways in Pakistan
}

\author{
Amir Detho \\ Department of Energy \& Environment \\ Engineering, Quaid-e-Awam University \\ of Engineering, Science \& Technology, \\ Nawabshah, Pakistan \\ aamir_detho@yahoo.com
}

\author{
Saleem Raza Samo \\ Department of Energy \& Environment \\ Engineering, Quaid-e-Awam University \\ of Engineering, Science \& Technology, \\ Nawabshah, Pakistan \\ sfaizsamo@yahoo.com
}

\author{
Kishan Chand Mukwana \\ Department of Energy \& Environment \\ Engineering, Quaid-e-Awam University \\ of Engineering, Science \& Technology, \\ Nawabshah, Pakistan \\ mukwana_99@yahoo.com
}

\author{
Imdad Ali Memon \\ Department of Mechanical Engineering \\ Quaid-e-Awam University of Engineering, Science \& \\ Technology, Nawabshah, Pakistan \\ engineerimdad@yahoo.com
}

\author{
Umair Ahmed Rajput \\ Department of Mechanical Engineering \\ Quaid-e-Awam University of Engineering, Science \& \\ Technology, Nawabshah, Pakistan \\ engr.umair@quest.edu.pk
}

\begin{abstract}
In Pakistan, the number of roads and highways is increasing along with the number of road traffic accidents (RTAs). Many researchers attempted to collect data of RTAs and to investigate their causes. Keeping those causes and reasons for RTAs in mind, remedies to prevent RTAs on the highways in Pakistan are proposed to make the roads and highways safer for traveling.
\end{abstract}

Keywords-causes of RTAs; road traffic accidents (RTAs); proposed remedies

\section{INTRODUCTION}

In most RTAs in Pakistan, the main cause is the negligence of drivers, although mechanical faults and road deficiencies play major roles in accident occurrences. The highways were initially used as feeder to the railways in Pakistan, but nowadays, they serve not only travellers but also agricultural producers, users and suppliers. Agricultural products supply main markets and are linked to larger inland markets all over the country by the Karachi port. Highways present phenomenal increase in length, from $249,972 \mathrm{~km}$ in $2000-01$ to $263,356 \mathrm{~km}$ by $2015-16$ and in the number of vehicles from 4,701,600, in 2000-01 to 17,317,600 in 2015-16 [1]. Generally highways are of single or double lane. The maintenance and construction of roads are under the State Government and National Highway Department.

\section{PREVIOUS RESEARCH SUMMARY}

For this work, extensive literature survey was carried out to determine the findings in the area of RTA causes. Authors in [2] took data from Pakistan bureau of statistics to fit linear, quadratic, cubic, logarithmic, inverse, exponential growth, logistic-curve and compound models for prediction. Data is summarized in Table I. Authors in [3] state that road studies and road safety learning is very necessary for the road user. They propose the introduction of road safety for pre schooling students through animal world stories. Elementary (primary) and middle level students must be aware and give a proper guidance about the sidewalk, road signs etc. Higher level students must be able to learn about defensive driving, breaking distance, alcohol hazards and reaction times. Random alcoholic blood concentration tests must be conducted along the road sides. It is concluded that the adoption of strict rules and regulations, more comprehensive rules and traffic controlling devices are essential. Public transport drivers should have basic first aid training. RTAs are globally the 8th leading cause of death and, according to WHO, RTAs will become the 3rd cause of death by the year 2020, if not controlled properly [4, 13]. The available data is not trustworthy due to under reporting, however, RTAs are one of the leading causes of death and injury worldwide. Author in [5] states that huge losses due to road accidents were reported in Tanzania, something that urged the government to take measures, however, the road accidents still kept increasing. A research was conducted, in a survey form to investigate the possible reasons of the road accidents. In the survey, participants were asked their opinion regarding the reasons of RTAs. It was identified that driver mistakes were the main reason of the accidents. It was concluded that drivers should be better trained before they acquire their license.

RTAs cause not only economic losses but also intangible consequences such as pain, grief etc. [6]. The increasing number of vehicles is the one of the major causes of RTAs. For reducing the impact of road accidents, many safety programs have been organized. Authors in [6] concluded that for reducing RTA number, safety programs of developed countries should be implemented. A little amount of research has been conducted on RTAs in India, which is the second-largest 
populated country in the world. To make the policies (regarding prevention of the road accidents) workable and effective, the safety plan must be based on local research and evidence. These plans must be designed to suit the local environment and circumstances [7]. Flow complexity on highways is the main reason for RTAs. It is estimated that 12 persons (in 100 accidents) were killed in 2011, whereas 7 persons were killed (in 100 accidents) in 2001. Because of damaged roads in rural areas, road accidents are likely to happen [8]. Author in [9] reports that in 2010, 10 RTAs in every minute have been reported and one death caused by RTAs occurred every 4 minutes. He concluded that it is difficult for the government to solve this problem alone. Authors in [10] state that the abrupt increment in the number of vehicles on the same infrastructures is the major cause of the increased highway accidents in Kerala. Authors in [11], with the help of the geographic information system (GIS), identified RTA "black spots". Author in [12] collected data of the road accidents in Kerala from 2010 to 2016 . He found that 12 deaths occur per 100 accidents in 2016 . Nowadays, road traffic safety has become an issue of major concern. In Pakistan, population increases along with traffic control problems. RTA related fatalities and injuries have great impact on the socioeconomic development. According to World Health Organization [13], each year an estimated 1.2 millions of people lose their lives and around 50 millions get injured due to RTAs worldwide. RTAs are caused by technical faults, dangerous driving, bad weather, road design and signage. However, in terms of automobile technology, safety has been achieved at a certain level. Our research group conducted a two-year survey on Hyderabad-Karachi Highway in terms of traffic accidents, loss of lives and vehicles, and RTA causes [14]. Results revealed that careless driving is the major cause of RTAs on the motorway. Data regarding loss of human lives and damaged vehicles in RTAs due to different reasons are summarized in Table II.

TABLE I. ROAD TRAFFIC ACCIDENTS DURING 2006 - 2016

\begin{tabular}{|c|c|c|c|c|c|c|}
\hline \multirow{2}{*}{ Year } & \multirow{2}{*}{$\begin{array}{c}\text { Number of } \\
\text { accidents }\end{array}$} & \multicolumn{2}{|c|}{ Accidents } & \multicolumn{2}{|c|}{ Persons } & \multirow{2}{*}{$\begin{array}{l}\text { Vehicles } \\
\text { involved }\end{array}$} \\
\hline & & Fatal & Non-fatal & Killed & Injured & \\
\hline 2006-07 & 10466 & 4535 & 5931 & 5465 & 12875 & 11481 \\
\hline $2007-08$ & 10466 & 4610 & 5856 & 5615 & 12096 & 11456 \\
\hline 2008-09 & 9496 & 4145 & 5351 & 4907 & 11037 & 10322 \\
\hline 2009-10 & 9747 & 4378 & 5369 & 5280 & 11173 & 10496 \\
\hline 2010-11 & 9723 & 4280 & 5443 & 5271 & 11383 & 10822 \\
\hline 2011-12 & 9140 & 3966 & 5174 & 4758 & 10145 & 9986 \\
\hline 2012-13 & 8988 & 3884 & 5104 & 4719 & 9710 & 9876 \\
\hline 2013-14 & 8359 & 3500 & 4859 & 4348 & 9777 & 9423 \\
\hline 2014-15 & 7865 & 3214 & 4651 & 3954 & 9661 & 8949 \\
\hline 2015-16 & 9100 & 3591 & 5509 & 4448 & 11544 & 10636 \\
\hline
\end{tabular}

TABLE II. CASUALTIES, DAMAGES AND RTA CAUSES [14]

\begin{tabular}{|c|c|c|c|c|c|c|c|}
\hline \multirow{2}{*}{ Year } & Damages & Totals & \multicolumn{5}{|c|}{ CAUSES } \\
\cline { 4 - 8 } & & $\begin{array}{c}\text { Careless } \\
\text { driving }\end{array}$ & $\begin{array}{c}\text { Tire } \\
\text { burst }\end{array}$ & $\begin{array}{c}\text { Brake } \\
\text { failure }\end{array}$ & $\begin{array}{c}\text { Road } \\
\text { Condition }\end{array}$ & $\begin{array}{c}\text { Pedestrian } \\
\text { Crossing }\end{array}$ \\
\hline \multirow{3}{*}{2015} & Deaths & 56 & 27 & 16 & 9 & 3 & 1 \\
\cline { 2 - 8 } & Injuries & 170 & 90 & 36 & 28 & 16 & 0 \\
\cline { 2 - 8 } & Vehicles & 141 & 93 & 19 & 20 & 4 & 5 \\
\hline \multirow{2}{*}{$\mathbf{2 0 1 6}$} & Deaths & 53 & 19 & 7 & 14 & 13 & 0 \\
\cline { 2 - 8 } & Injuries & 123 & 50 & 24 & 22 & 24 & 3 \\
\cline { 2 - 8 } & Vehicles & 110 & 52 & 12 & 15 & 30 & 1 \\
\hline
\end{tabular}

\section{PROPOSED REMEDIES TO PREVENT RTAS}

RTAs not only take human lives and damage properties but also can lead to social problems. It is important to prevent or at least minimize RTAs. Keeping in mind this and the RTA causes, the following are the proposed remedies to prevent/minimize RTAs in Pakistan.

- It is necessary to provide proper education to drivers and proper driving habits should be enforced.

- The process of issuing driving licenses must be tough and the license should be issued after proper examinations.

- In the presence of bad road conditions, appropriate sign boards should be erected along the highways.

- Vehicles not in a good condition should not be allowed to enter motorways.

- The roads should be maintained properly. The black spots (where repeated accidents have happened) should be looked into for proposing possible remedial measures.

- A nationwide campaign should be launched to educate and warn people about traffic laws. Regular inspections should be made necessary for new and existing roads.

- Over speeding offenders should stop being conveniently ignored by the enforcing agencies.

- Commercial vehicles should be road worthy and a system of banning the entry of such vehicles in bad shape should be implemented.

- A proper check should be done regarding all safety aspects before allowing rickshas on highways.

- While designing new highways, proper attention should be given on facilities for pedestrian and handicapped people.

- Immediate legislation should be undertaken without any delay.

- Authorities and parents should discourage underage kids from driving.

- It is quite difficult to drive in night time due to the head lights of vehicles coming from the opposite side. Therefore it is highly recommended to divide the lanes by walls of sufficient height or vegetation.

- To stops animals, fences along the road should be erected.

- Motorcyclists, bicyclists and bull/donkey/horse carts should be prohibited from entering highways.

- Sign boards and traffic signals must be provided wherever it is necessary.

- Every highway should be made to have three lanes in each direction. On two lanes would be sufficient for roads.

- One of the major causes of RTAs in Pakistan highways is that goods are transported on trucks and trailers. To prevent these from running on roads, the railway system should be improved. 
- It should be mandatory for trucks and tractors to have lights behind the trolleys.

\section{SUMMARY AND CONCLUSIONS}

Based on literature and data review, some remedy measures were proposed to prevent RTAs on highways and roads.

\section{REFERENCES}

[1] Pakistan Economic Survey, available at: http://121.52.153.178:8080 /xmlui/handle/123456789/14893

[2] M. Imran, J. A. Nasir, "Road Taffic Accidents, Prediction in Pakistan", The Professional Medical Journal, Vol. 22, No. 6, pp. 705-709, 2015

[3] N. Jha, D. K. Srinivasa, G. Roy, S. Jagdish, "Epidemiological Study of Road Traffic Accident Cases: A study from South India", Indian Journal of Community Medicine, Vol. 29, No. 1, pp. 20-24, 2004

[4] G. Al-Haji, Road Safety Development Index: Theory, Philosophy and Practice, PhD Thesis, Linkoping University of Technology, 2007

[5] R. R. Akkarro, "Peoples Opinion on the Causes of Road Accidents in selected places of Tanzania", European Journal of Social Sciences, Vol. 9, No. 4, pp. 615-626, 2009

[6] B. B. Pillai, J. Kurian, "Causes and consequences of road accidents in Kerala", International Journal of Research in IT \& Management, Vol. 1, pp. 83-95, 2011

[7] M. M. Ruikar, "National Statistics on Road Traffic Accidents in India", Journal of Orthopedics, Traumatology and Rehabilitation ,Vol. 6, No.1, pp. 1-6, 2013

[8] B. V. Sreekumar, V. Sreedevi, "Impact of Road Accidents in Kerala During 2001 to 2011-A Case Study", Vol. 6, No. 1, pp. 51-57, 2014

[9] D. Pawan, "Road Safety and Accident Prevention in India", International Journal of Advanced Engineering Technology, Vol. 5, No. 2, pp. 64-68, 2014

[10] B. B. Pillai, G. D. Singh, "Scenario of Road Accidents in Kerala and its ill Effects", International Journal in Management and Social Science,Vol. 3, No. 3, pp. 559-567, 2015

[11] L. Isen, A. Shibu, M. S. Saran, "Identification and Analysis of Black spots using Geographic information system", International Journal of Innovative Research in Science, Engineering \& Technology,Vol. 2, No. 1, pp. 131-139, 2013

[12] A. Chand, "A case study of raod accidents in Kerala during 2010 to 2016", International Journal of Innovative Research in Science, Engineering \& Technology, Vol. 6, No. 4, pp. 199-203, 2017

[13] World Health Organization (WHO), Word Report on Road Traffic Injury Preventation: Summary, WHO, 2004

[14] A. Detho, S. R. Samo, K. C. Mukwana, K. A. Samo, A. A. Siyal, "Evaluation of Road Traffic Accidents (RTAs) on Hyderabad Karachi M-9 Motorway Section", Engineering, Technology \& Applied Science Research, Vol. 8, No. 3, pp. 2875-2878, 2018 